\title{
Evaluation of ubiquitin C-terminal hydrolase-L1 enzyme levels in patients with epilepsy
}

\author{
Avaliação dos níveis de enzima ubiquitina C-terminal hidrolase-L1 em pacientes com epilepsia \\ Ibrahim Halil YASAK', Mustafa YILMAZ², Murat GÖNEN³, Metin ATESCELIK², Mehtap GURGER², \\ Nevin ILHAN4 , Mehmet Cagri GOKTEKIN²
}

\begin{abstract}
Objective: Ubiquitin C-terminal Hydrolase-L1 (UCH-L1) enzyme levels were investigated in patients with epilepsy, epileptic seizure, remission period, and healthy individuals. Methods: Three main groups were evaluated, including epileptic seizure, patients with epilepsy in the non-seizure period, and healthy volunteers. The patients having a seizure in the Emergency department or brought by a postictal confusion were included in the epileptic attack group. The patients having a seizure attack or presenting to the Neurology outpatient department for follow up were included in the non-seizure (remission period) group. Results: The UCH-L1 enzyme levels of 160 patients with epilepsy (80 patients with epileptic attack and 80 patients with epilepsy in the non-seizure period) and 100 healthy volunteers were compared. Whereas the UCH-L1 enzyme levels were $8.30(I Q R=6.57-11.40) \mathrm{ng} / \mathrm{mL}$ in all patients with epilepsy, they were detected as 3.90 $(I Q R=3.31-7.22) \mathrm{ng} / \mathrm{mL}$ in healthy volunteers, and significantly increased in numbers for those with epilepsy $(\mathrm{p}<0.001)$. However, whereas the $\mathrm{UCH}-\mathrm{L} 1$ levels were $8.50(\mathrm{IQR}=6.93-11.16) \mathrm{ng} / \mathrm{mL}$ in the patients with epileptic seizures, they were $8.10(\mathrm{IQR}=6.22-11.93) \mathrm{ng} / \mathrm{mL} \mathrm{in}$ the $\mathrm{non}-$ seizure period, and no significant difference was detected $(p=0.6123)$. When the UCH-L1 cut-off value was taken as $4.34 \mathrm{mg} / \mathrm{mL}$ in Receiver Operating Characteristic (ROC) Curve analysis, the sensitivity and specificity detected were 93.75 and 66.00\%, respectively (AUG=0.801; $\mathrm{p}<0.0001 ; 95 \% \mathrm{Cl} 0.747-0.848)$ for patients with epilepsy. Conclusion: Even though UCH-L1 levels significantly increased more in patients with epilepsy than in healthy individuals, there was no difference between epileptic seizure and non-seizure periods.
\end{abstract}

Keywords: Epilepsy; Ubiquitin; Seizures.

\section{RESUMO}

Objetivo: Níveis da enzima ubiquitina C-terminal hidrolase-L1 (UCH-L1) foram investigados em pacientes com epilepsia, crise epiléptica, período de remissão e indivíduos saudáveis. Método: Foram avaliados três grupos principais, incluindo crise epiléptica, epilepsia no período não convulsivo e voluntários saudáveis. Pacientes com convulsão no departamento de emergência ou trazidos por confusão pós-ictal foram incluídos no grupo de crise epiléptica. Os pacientes que tiveram crise epiléptica ou foram ao ambulatório de Neurologia para acompanhamento foram incluídos no grupo não convulsivo (período de remissão). Resultados: Os níveis da enzima UCH-L1 de 160 pacientes com epilepsia (80 pacientes com crise epiléptica e 80 pacientes com epilepsia no período não convulsivo) e 100 voluntários saudáveis foram comparados. Enquanto os níveis da enzima UCH-L1 foram 8,30 (IQR=6,57-11,40) ng/mL em todos os pacientes com epilepsia, os níveis detectados foram de 3,90 (IQR=3,31-7,22) ng/mL em voluntários saudáveis e aumentaram significativamente na epilepsia ( $p<0,001)$. No entanto, ao passo que os níveis de UCH-L1 foram 8,50 (IQR=6,93-11,16) ng/mL nos pacientes com crise epiléptica, foram 8,10 (IQR=6,22-11,93) ng/mL no período não convulsivo, e nenhuma diferença significativa foi detectada ( $p=0,6123$ ). Quando o valor de corte de UCH-L1 foi considerado 4,34 mg/mL com base na análise da curva ROC, sensibilidade e especificidade foram detectadas como 93,75 e 66,00\%, respectivamente (AUG=0,801; $P<0,0001$; IC95\% 0,747-0,848) para os pacientes com epilepsia. Conclusão: Embora os níveis de UCH-L1 tenham aumentado significativamente nos pacientes com epilepsia em relação aos indivíduos saudáveis, não foi observada diferença entre crise epiléptica e períodos não convulsivos.

Palavras-chave: Epilepsia; Ubiquitinas; Convulsões.

\section{INTRODUCTION}

Epilepsy, which is one of the most frequent reasons to be admitted at the Emergency department due to a seizure, is a clinical picture occurring as a result of sudden, abnormal, and hypersynchronous discharge of neuronal groups, which take part in cortical or subcortical regions of the central nervous system (CNS) and have a recurrent characteristic in

\footnotetext{
${ }^{1}$ Harran University, Emergency Deparment of Medicine, Sanliurfa, Turkey.

2 University of Firat, Emergency Medicine, Elazig, Turkey.

${ }^{3}$ Firat Universitesi Tip Fakultesi, Neurology, Elazig, Turkey.

${ }^{4}$ Firat Universitesi, Biochemistry Department, Elazig, Turkey.

Ibrahim Halil YASAK ${ }^{1}$ (D) https://orcid.org/0000-0002-3718-9519; Mustafa YILMAZ2 (iD) https://orcid.org/0000-0002-4457-428X;

Murat GÖNEN ${ }^{3}$ iD https://orcid.org/0000-0002-6399-7755; Metin ATESCELIK ID https://orcid.org/0000-0003-1201-7355;

Mehtap GURGER² (iD https://orcid.org/0000-0002-5209-2088; Nevin ILHAN4 id https://orcid.org/0000-0002-0208-8929;

Mehmet Cagri GOKTEKIN² (D) https://orcid.org/0000-0001-7911-8965

Correspondence: Mustafa Yilmaz; E-mail:drmylmz@hotmail.com

Conflicts of interest: There is no conflict of interest to declare.

Received on October 11, 2019; Received in its final form on December 26, 2019; Accepted on February $26,2020$.
} 
general. Brain damage, which results in occurring as a spontaneous seizure and causes the activation of a change in the molecular and cellular levels, plays a role in the etiopathogenesis of epilepsy ${ }^{1}$. The complaints associated to a seizure constitute approximately 1 to $2 \%$ of all Emergency department admissions ${ }^{2,3}$.

Ubiquitin is required for cellular cleaning of the ubiquitin C-terminal hydrolase-L1 (UCH-L1) abnormal proteins, which are important regulators and specially expressed in a high incidence of neurons. The UCH-L1 neuron-specific 9.5 gene product is a protein, which was used as a histological marker for neurons and is a promising agent as a biomarker in traumatic brain damage. The proteins, which go to deterioration over the proteasomal pathway, play an important role in removing oxidized or increased proteins in the normal or pathologic situations by joining the ubiquitination process ${ }^{4}$. There are three relevant enzymes in this class, including UCH-L1, L2, and L3. However, only the UCH-L1 reaches high levels in the central nervous system. The UCH-L1 mainly constitutes 1 to $5 \%$ of total soluble brain proteins. These enzymes are responsible for increasing or removing ubiquitin in the ATP relevant proteasome pathway needed for metabolism ${ }^{5}$.

The UCH-Ll's best-known aspect is to function as a deubiquitinating enzyme and hydrolyze ubiquitin $\mathrm{C}$ terminal esters and amides. Moreover, it has a ubiquitin ligase activity, which uses alpha-synuclein as a substrate ${ }^{6}$. It was shown that this molecule is a gene polymorphism's dysfunction in neurodegenerative diseases, such as Parkinson or Alzheimer diseases, and its expression is regulated down by subjecting it to an oxidative modification $^{7.89,10}$. It was reported that the UCH-L1 started to increase in the first 3 to 6 hours and reached its peak level in the $24^{\text {th }}$ hour for the situations, in which there were neuron damages, such as traumatic brain damage and strokes ${ }^{11}$.

In our study, we investigated the UCH-L1 enzyme levels within the epileptic seizure and non-seizure periods in patients with epilepsy.

\section{METHODS}

The study was started after obtaining the approval by the local university's ethics committee and all patients signed the written informed. The study patients were gathered in three main groups, including epileptic seizure period, nonseizure period, and healthy volunteers. The patients having a seizure in the Emergency department or brought by a postictal confusion were included in the epileptic seizure group $(n=80)$. The patients having an epileptic seizure or coming to the Neurology outpatient department for follow up were included in the non-seizure period (remission) group ( $\mathrm{n}=80$ ).

The patients included in the present study were aged 18 years and older, had a seizure in the Emergency department, had entered the Emergency department after a seizure, had been diagnosed with an epileptic seizure, had given their approval to participate in the study, had received the administration of a single drug (valproic acid), two drugs (valproic acid and phenytoin), and three drugs (valproic acid, phenytoin and lamotrigine) as an antiepileptic treatment, and regularly used these drugs.

The patients excluded from the study were those who had seizure due to a metabolic disorder or trauma, who did not regularly use their antiepileptic drugs, did not receive the antiepileptic drugs defined in the inclusion criteria of the study, or those who refused to participate.

The blood sample was taken from the antecubital vein for the plasma UCH-L1 level measurements. Their plasma was taken by centrifuging at 5,000 RPM for 10 minutes at $4^{\circ} \mathrm{C}$ after waiting for their coagulation for 15-30 minutes. The samples were kept at $-20^{\circ} \mathrm{C}$. The UCH-L1 levels were studied by ELISA kits in accordance with the kit content by using ELISA washer and reader.

The Statistical Package for the Social Sciences (SPSS 21, Chicago, IL, USA) statistics program was used in the data analysis. The continuous distribution of variables was detected by Kolmogorov-Smirnov and Shapiro-Wilk normality tests in the data analysis. Whereas the parametric data were expressed as a mean or standard deviation, non-parametric data were represented as a medium (minimum-maximum) or median (IQR: interquartile range, 25/75 percentile), and categorical data were submitted as a percentage. Kruskal-Wallis test was used in the comparison of more than two independent groups that did not conform to the normal distribution. Mann-Whitney U test was used in the detection of a relation between dual groups. Spearman's correlation test was used in the non-parametric variables' correlation analysis. Chi-square test (cross-tab) was used in the categorical variables' comparison. Receiver Operating Characteristic (ROC) Curve analysis was made by using the UCH-L 1 levels of patients with epilepsy and healthy individuals. The ROC Curve analysis results given considered a $\%$ for specificity and a $\%$ for sensitivity [area under ROC curve (AUC), p, and 95\% confidence interval $(95 \% \mathrm{CI})] . \mathrm{P}<0.05$ was significant in all analysis results.

\section{RESULTS}

Whereas 160 out of 260 individuals included in our study were the patients with epilepsy, 100 of them (male/ female=59/41) constituted the healthy control group. The diagnosis of patients with epilepsy time was a mean of $12.77 \pm 10.80$ /year. Epileptic patients' mean age was 3715.67 years, while the healthy controls' mean age was $38.07 \pm 16.49$ years. There was no difference between the groups in terms of sex $(\mathrm{p}=0.968)$ and age $(\mathrm{p}=0.768)$. The UCH-L1 median levels was $8.30 \mathrm{ng} / \mathrm{mL}(\mathrm{IQR}=6.57-11.40)$ in all patients with epilepsy and $3.90 \mathrm{ng} / \mathrm{mL}(\mathrm{IQR}=3.31-7.22)$ in the healthy controls, being significantly higher in the former group $(\mathrm{p}<0.0001)$ 
(Figure 1). The basic demographic and clinical data of epileptic and healthy individuals is shown in Table 1.

A total of 80 out of 160 patients with epilepsy (M/ $\mathrm{F}=55 / 25$ ) included in our study presented to the emergency department due to an epileptic seizure. The mean duration of the last seizure in these patients was $5.57 \pm 4.90 / \mathrm{min}$, and there was no correlation between seizure duration and UCH-L1 levels ( $r=-0.091 ; p=0.254)$. The blood samples of the patients having an epileptic seizure were approximately taken within 45 minutes. The remaining 80 patients with epilepsy $(M / F=29 / 41)$ consisted of the epileptic patients who were admitted to the Neurology outpatient department for control, and they did not have an active seizure in the remission period. Whereas the median UCH-L1 level in the epileptic crisis group was $8.50(\mathrm{IQR}=6.93-11.16) \mathrm{ng} / \mathrm{mL}$,

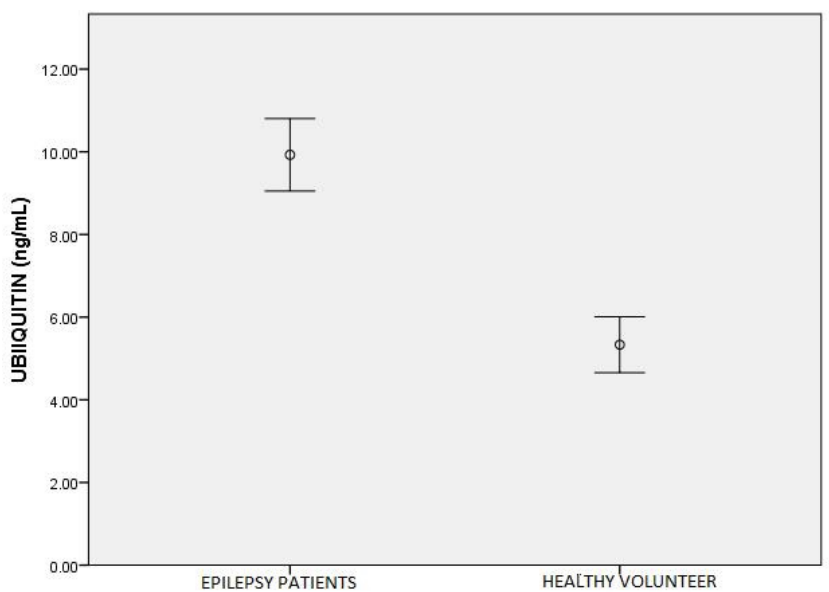

Figure 1. Distribution of UCH-L1 levels of epilepsy patients and healthy control patients.

Table 1. Comparison of demographic data epilepsy patients and healthy Control Group patients.

\begin{tabular}{lccc|}
\hline Parameter & $\begin{array}{c}\text { Patients with } \\
\text { epilepsy }\end{array}$ & $\begin{array}{c}\text { Healthy } \\
\text { Control }\end{array}$ & p-value \\
\hline $\mathrm{N}(\mathrm{M} / \mathrm{F})$ & $160(94 / 66)$ & $100(59 / 41)$ & 0.968 \\
\hline Age (years) & $37.29 \pm 15.67$ & $38.07 \pm 16.49$ & 0.768 \\
\hline Mean Arterial Pressure & $88.54 \pm 9.34$ & $108.23 \pm 13.72$ & 0.000 \\
\hline Pulse & $87.65 \pm 14.20$ & $86.02 \pm 14.51$ & 0.333 \\
\hline $\begin{array}{l}\text { Respiratory Rate } \\
\text { (breath /minute) }\end{array}$ & $18.57 \pm 1.93$ & $18.70 \pm 1.69$ & 0.552 \\
\hline Fewer (C) & $36.72 \pm 0.42$ & $36.64 \pm 0.43$ & 0.138 \\
\hline sPO2 & $96.34 \pm 1.88$ & $96.40 \pm 2.03$ & 0.645 \\
\hline GCS & $14.02 \pm 1.20$ & 15.00 & 0.000 \\
\hline $\begin{array}{l}\text { Epilepsy Diagnosis } \\
\text { Period }\end{array}$ & $12.77 \pm 10.80$ & ---- & \\
\hline Attack Frequency & $23.51 \pm 27.56$ & ---- & \\
\hline Last Seizure & $64.90 \pm 87.30$ & ---- & \\
\hline Spasm Period & $5.57 \pm 4.90$ & ---- & \\
\hline UCHL-1 Median & 8.30 & 3.90 & $<0.0001$ \\
\hline (IQR) (ng/mL) & $(6.57-11.40)$ & $(3.31-7.22)$ & \\
\hline
\end{tabular}

the median UCH-L1 value in patients in the remission period was 8.105 (IQR=6.22-11.93) ng/mL, and these levels were not different ( $\mathrm{p}=0.507$ ) (Figure 2). The basic demographic and clinical data of the patients from this group is given in Table 2.

The mean age of patients admitted with an epileptic seizure was $36.3 \pm 15.4$ years, whereas the mean age of patients in the remission period was $38.2 \pm 15.1$ years, and there was no statistical difference $(\mathrm{p}=0.418)$. Men were more common than women in the group of patients admitted with an epileptic seizure, while women were more common in the nonseizure (remission) group ( $\mathrm{p}=0.010)$.

The ROC Curve analysis comparing UCH-L1 levels between patients with epilepsy and healthy volunteers yielded sensitivity and specificity values of $93.75 \%$ and $66.00 \%$,

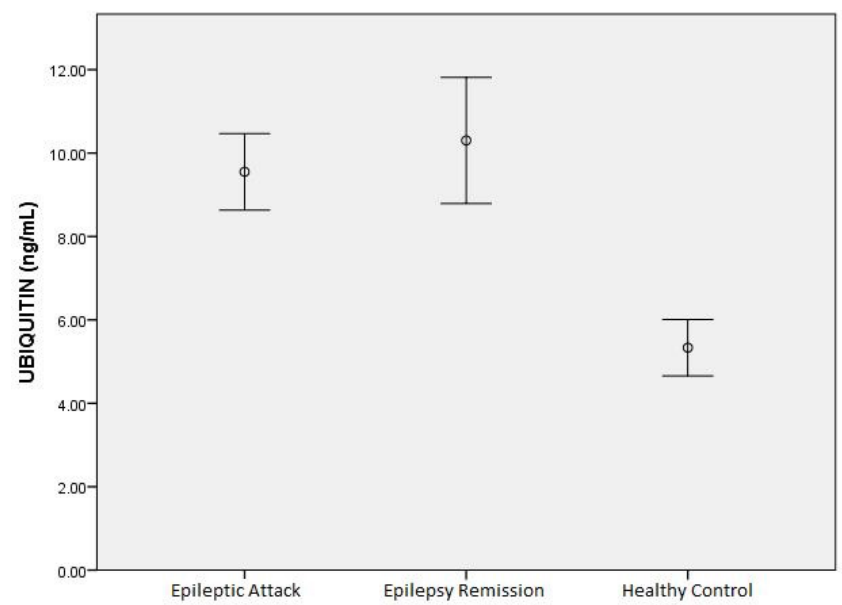

Figure 2. Distribution of UCH-L1 levels in the groups with epileptic crisis, remission, and healthy controls.

Table 2. Comparison of demographic data of patients in epileptic attacks and remission periods.

\begin{tabular}{lccc}
\hline Parameter & $\begin{array}{c}\text { Epilepsy } \\
\text { Attack }\end{array}$ & $\begin{array}{c}\text { Epilepsy } \\
\text { Remission }\end{array}$ & p-value \\
\hline N (M/F) & $80(55 / 25)$ & $80(39 / 41)$ & 0.010 \\
\hline Age (years) & $36.3 \pm 15.4$ & $38.2 \pm 15.1$ & 0.418 \\
\hline Mean Arterial Pressure & $90.41 \pm 11.90$ & $86.66 \pm 5.19$ & 0.057 \\
\hline Pulse & $84.24 \pm 14.60$ & $91.06 \pm 12.99$ & 0.001 \\
\hline Respiratory Rate & $18.76 \pm 1.55$ & $18.3750 \pm 2.25$ & 0.197 \\
(breath /minute) & $36.59 \pm 0.42$ & $36.85 \pm 0.38$ & 0.135 \\
\hline Fewer(ㅇ) & $96.45 \pm 2.15$ & $96.24 \pm 1.56$ & 0.161 \\
\hline sPO2 & $13.04 \pm 0.99$ & 15 & $<0.001$ \\
\hline GCS & $13.46 \pm 10.71$ & $12.09 \pm 10.92$ & 0.488 \\
\hline $\begin{array}{l}\text { Epilepsy Diagnosis } \\
\text { Period }\end{array}$ & $26.2 \pm 26.6$ & $20.8 \pm 28.4$ & 0.037 \\
\hline Attack Frequency & $5.94 \pm 5.15$ & $5.21 \pm 4.63$ & 0.397 \\
\hline Spasm Period & $1.7 \pm 0.7$ & $1.6 \pm 0.7$ & \\
\hline AEM Use Number & 8.50 & 8.10 & 0.507 \\
\hline $\begin{array}{l}\text { UCHL-1 Median } \\
\text { (IQR) (ng/mL) }\end{array}$ & $(6.93-11.16)$ & $(6.22-11.93)$ & \\
\hline
\end{tabular}


respectively, for the cut-off value of $4.34 \mathrm{ng} / \mathrm{mL}$ (AUC=0.80, 95\% CI 0.747-0.848; $\mathrm{p}<0.0001$ ) (Figure 3).

No significant differences were found between UCH-L 1 levels according to the antiepileptic drug regimen (valproic acid in single-drug users, valproic acid and phenytoin, in double-drug users, and valproic acid, phenytoin and levetiracetam in triple-drug users; Table 3).

\section{DISCUSSION}

Epilepsy is one of the most common neurological diseases. The disease incidence rate is approximately $1 \%$ in the world. It is usually a chronic condition and sometimes requires a lifelong treatment ${ }^{12}$. Although many conditions may be the cause of epilepsy, no specific etiology is found in most cases $^{13,14}$.

Although there were studies conducted to define the biochemical indicators in cerebrospinal fluid (CSF) or plasma for monitoring the diagnosis of patients with an epileptic seizure and the disease's progression, the use of these indicators is not indicated in the clinic ${ }^{15,16,17,18}$. The Ubiquitin-proteasome

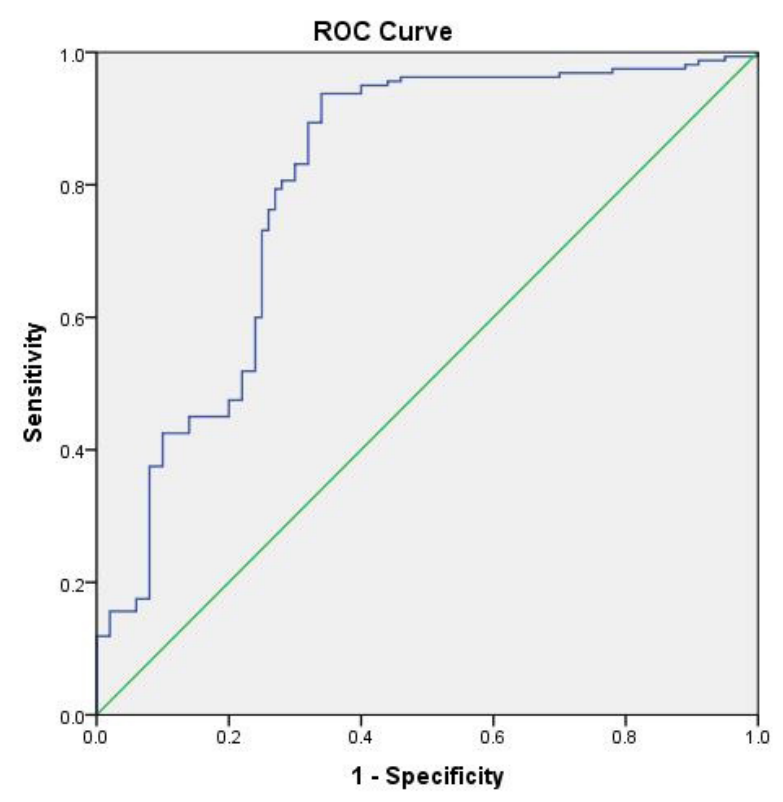

Figure 3. Epilepsy patients and healthy individuals in ROC curve analysis.

Table 3. Comparison of used antiepileptic druge regimen and UCH-L1 level.

\begin{tabular}{lcccc}
\hline & $\mathrm{n}(\mathrm{M} / \mathrm{F})$ & UCH-L1 & chi-square & $\mathrm{p}$-value \\
\hline Single & 82 & 8.416 & & \\
Medicine & $(43 / 39)$ & $(6.570011 .859)$ & & \\
Double & 55 & 8.540 & & \\
Medicine & $(36 / 19)$ & $(7.266011 .055)$ & 3.391 & 0.184 \\
Triple & 23 & 7.182 & & \\
Medicine & $(15 / 8)$ & $(5.396010 .640)$ & & \\
\hline
\end{tabular}

system plays a key role in the cell cycle, signal transduction, transcriptional regulation, DNA repair, stress response, programmed cell death, and antigen representation ${ }^{19}$. The UCHL1 task is to function as a deubiquitination enzyme and hydrolyze the ubiquitin $\mathrm{C}$ terminal esters and amides ${ }^{6}$, because it takes part in this system.

The UCH-L1 is also a biomarker, which has gained popularity in recent years, especially for the diseases associated to the central nervous system, considering it is only localized in neurons. Gong et al. ${ }^{20}$ detected in their study that neurodegenerative disorders, such as Parkinson, Huntington and Alzheimer diseases, are associated to a change in the UCH-L1 protein activity. Setsuie and Wada ${ }^{21}$ reported that the UCH-L1 had a role in the pathogenesis of Parkinson and Alzheimer disease in a similar. Mondello et al. ${ }^{22}$ detected that the UCH-L1 level decreased in a study performed with 52 Parkinson disease patients. Papa et al. ${ }^{5}$ found that the UCH-L1 levels were high in a study with 41 patients with a traumatic brain injury. Ren et al. ${ }^{11}$ stated that the UCH-L1 level was significantly more than in the control group in a study with 79 patients who suffered ischemic strokes. These studies present qualitative information in the measurement of markers that are sensitive to brain damage after a stroke or head trauma.

The UCH-L1 is reported to increase in the plasma in the first three to six hours and to reach peak levels after 24 hours in patients with stroke and traumatic brain damage, due to neuronal damage ${ }^{11}$. Although there are not enough studies investigating UCH-L1 levels in epilepsy, a few studies investigated UCH-L1 levels in the plasma and $\mathrm{CSF}^{22,23}$. Li et al. ${ }^{23}$ determined UCH-L1 levels in CSF samples from 33 epileptic patients presenting with seizure to the Emergency department and found that the levels were significantly higher among patients in the first 24 hours in comparison to healthy controls. Mondello et al..$^{22}$ investigated UCH-L1 levels in plasma and CSF of 52 epileptic patients who were admitted to the Emergency department with a seizure complaint. They also detected that the UCH-L1 levels were significantly higher than in the control group, because the UCHL1 levels were measured in the CSF in the first 48 hours and in the plasma in the first 12 hours. In our study, the blood samples of patients admitted with a seizure complaint were taken within 45 minutes after the attack. Since this duration is shorter than the duration specified in previous studies, it may explain that no difference emerged when comparing UCH-L1 levels between patients in the seizure and non-seizure periods.

Ubiquitin C-terminal hydrolase-L1 level of age and gender was generally not associated with sex. In addition, it was observed that different results were obtained in relation to age. Mondello et al. ${ }^{22}$ showed a strong correlation between the CSF and plasma UCH-L1 levels with age, and they also detected that the UCH-L1 levels did not have a relation with sex. However, Li et al. ${ }^{23}$ detected that the UCH-L1 level was 
not related to age and sex. . In our study, we detected that the $\mathrm{UCH}-\mathrm{L} 1$ level did not have a relation with age and

Li et al. ${ }^{23}$ reported that the mean seizure period of patients with an epileptic seizure was 13.6 minutes in the study, in which a relation between the UCH-L1 level and seizure durations of patients was investigated, and this seizure duration and UCH-L1 level showed a positive correlation. In our study, no correlation was found between the seizure duration and the UCH-L1 level. In the study by Li et al. ${ }^{23}$, even though a treatment was administered to 19 patients as a monotherapy and to six patients as a polytherapy, they did not find a significant difference between the UCH-L1 levels of epileptic patients who received treatment or not, although only eight patients did not receive any treatment. Likewise, in our study, no relation was determined between the antiepileptic drug regimen and UCH-L1 levels.

The differential diagnosis of epileptic and non-epileptic seizures varies based on age and clinical presentation of seizures. Non-epileptic seizures are divided into two groups: physiological and psychogenic. Psychogenic nonepileptic seizures (PNES) are more common and are considered within the category of psychoneurological disorders in which the symptoms are originally psychological, but with a neurological manifestation. They are also considered a physical reflection of psychological stress, which is an episode of paroxysmal behavioural changes that resembles epileptic seizures but is not accompanied by EEG changes and central nervous system dysfunction. PNES can mimic many types of epilepsy and may also accompany $i^{24}$. Moreover, the fact that epileptic seizures can also be observed in $10.7 \%$ of PNES patients further complicates the differential diagnosis ${ }^{25}$. EEG, imaging techniques (e.g., CT, MR, SPECT) and other diagnostic methods (video-EEG monitoring) are used to differentiate between PNES and epilepsy. However, research to find a parameter that can be used as a biomarker is still being undertaken. One candidate which has attracted recent attention is prolactin. Several studies have examined the changes in prolactin levels after epileptic seizures and whether these changes are different from non-epileptic seizures. The American Academy of Neurology has recently published a review of 10 studies. In eight of these studies, it was found that postictal increase in serum prolactin level had a positive diagnostic value in terms of epilepsy, but the absence of an increase did not exclude epilepsy and no significant increase was observed in pseudo-seizures. In the other two studies, there was a statistically significant increase in serum prolactin levels in pseudo-seizures, but this increase was significantly lower when compared to those observed in epilepsy ${ }^{26}$. Shah reported that there was an average increase of $17 \%$ in serum prolactin levels after pseudo-seizures; therefore, an increase of at least 2 times could be considered significant for epilepsy ${ }^{27}$. UCHL-1 enzyme levels, which were found to be significantly increased compared to those in healthy controls in the present study, may be useful in differentiating epilepsy and PNES. These results need to be supported by further methodologically appropriate studies for proving the diagnostic value of UCHL-1 enzyme levels in the differentiation of epileptic seizures and PNES.

In conclusion, although the UCH-L1 levels increase significantly more in patients with epilepsy than in healthy individuals, it does not constitute a difference between the epileptic crisis and the remission period.

\section{ACKNOWLEDGMENTS}

The authors declare that they have no competing interests. This study was supported by University Scientific Research Projects Coordination Unit (FÜBAP: TF 1538).

\section{References}

1. Pitkänen A, Lukasiuk K. Molecular and cellular basis of epileptogenesis in symptomatic epilepsy. Epilepsy Behav. 2009 Jan;14 Suppl 1:16-25. https://doi.org/10.1016/j.yebeh.2008.09.023

2. Engel J Jr, Starkman S. Overview of seizures. Emergency medicine clinics of North America. 1994;12(4):895-923.

3. Huff JS, Melnick ER, Tomaszewski CA, Thiessen ME, Jagoda AS, Fesmire FM, et al. Clinical policy: critical issues in the evaluation and management of adult patients presenting to the emergency department with seizures. Ann Emerg Med. 2014 Apr;63(4):437-47. e15. https://doi.org/10.1016/j.annemergmed.2014.01.018

4. Diaz-Arrastia R, Wang KK, Papa L, Sorani MD, Yue JK, Puccio AM, et al. Acute biomarkers of traumatic brain injury: relationship between plasma levels of ubiquitin C-terminal hydrolase-L1 and glial fibrillary acidic protein. J Neurotrauma. 2014 Jan;31(1):19-25. https://doi. org/10.1089/neu.2013.3040

5. Papa L, Akinyi L, Liu MC, Pineda JA, Tepas III JJ 3rd, Oli MW, et al. Ubiquitin C-terminal hydrolase is a novel biomarker in humans for severe traumatic brain injury. Crit Care Med. 2010 Jan;38(1):138-44. https://doi.org/10.1097/CCM.0b013e3181b788ab

6. Chen F, Sugiura Y, Myers KG, Liu Y, Lin W. Ubiquitin carboxyl-terminal hydrolase $L 1$ is required for maintaining the structure and function of the neuromuscular junction. Proc Natl Acad Sci U SA. 2010 Jan;107(4):1636-41. https://doi.org/10.1073/pnas.0911516107

7. Gong B, Cao Z, Zheng P, Vitolo OV, Liu S, Staniszewski A, et al. Ubiquitin hydrolase Uch- $L 1$ rescues $\beta$-amyloid-induced decreases in synaptic function and contextual memory. Cell. 2006 Aug;126(4):77588. https://doi.org/10.1016/j.cell.2006.06.046

8. Leroy E, Boyer R, Auburger G, Leube B, Ulm G, Mezey E, et al. The ubiquitin pathway in Parkinson's disease. Nature. 1998 Oct;395(6701):451-2. https://doi.org/10.1038/26652

9. Castegna A, Aksenov M, Thongboonkerd V, Klein JB, Pierce WM, Booze $\mathrm{R}$, et al. Proteomic identification of oxidatively modified proteins in Alzheimer's disease brain. Part II: dihydropyrimidinase-related protein 2, $\alpha$-enolase and heat shock cognate 71.J Neurochem. 2002 Sep;82(6):1524-32. https://doi.org/10.1046/j.1471-4159.2002.01103.x 
10. Choi J, Levey Al, Weintraub ST, Rees HD, Gearing M, Chin LS, et al. Oxidative modifications and down-regulation of ubiquitin carboxylterminal hydrolase L1 associated with idiopathic Parkinson's and Alzheimer's diseases. J Biol Chem. 2004 Mar 26;279(13):13256-64. https://doi.org/10.1074/jbc.M314124200

11. Ren C, Zoltewicz S, Guingab-Cagmat J, Anagli J, Gao M, Hafeez A, et al. Different expression of ubiquitin C-terminal hydrolase-L1 and $\alpha$ ll-spectrin in ischemic and haemorrhagic stroke: potential biomarkers in diagnosis. Brain Res. 2013 Dec;1540:84-91. https:// doi.org/10.1016/j.brainres.2013.09.051

12. ACEP Clinical Policies Committee; Clinical Policies Subcommittee on Seizures. Clinical policy: critical issues in the evaluation and management of adult patients presenting to the emergency department with seizures. Ann Emerg Med. 2004 May;43(5):605-25. https://doi.org/10.1016/S019606440400068X

13. Nicoletti A, Reggio A, Bartoloni A, Failla G, Sofia V, Bartalesi F, et al. Prevalence of epilepsy in rural Bolivia: a door-to-door survey. Neurology. 1999 Dec;53(9):2064-9. https://doi.org/10.1212/ wnl.53.9.2064

14. Dent W, Helbok R, Matuja WBP, Scheunemann S, Schmutzhard E. Prevalence of active epilepsy in a rural area in South Tanzania: a door-to-door survey. Epilepsia. 2005 Dec;46(12):1963-9. https://doi. org/10.1111/j.1528-1167.2005.00338.x

15. Pitkänen A, Sutula TP. Is epilepsy a progressive disorder? Prospects for new therapeutic approaches in temporal-lobe epilepsy. Lancet Neurol. 2002 Jul;1(3):173-81. https://doi.org/10.1016/s14744422(02)00073-x

16. Palmio J, Peltola J, Vuorinen P, Laine S, Suhonen J, Keränen T. Normal CSF neuron-specific enolase and S-100 protein levels in patients with recent non-complicated tonic-clonic seizures. $J$ Neurol Sci. 2001 Jan;183(1):27-31. https://doi.org/10.1016/s0022510x(00)00478-0

17. Palmio J, Suhonen J, Keränen T, Hulkkonen J, Peltola J, Pirttilä T. Cerebrospinal fluid tau as a marker of neuronal damage after epileptic seizure. Seizure. 2009 Sep;18(7):474-7. https://doi. org/10.1016/j.seizure.2009.04.006
18. Thompson R, Doran J, Jackson P, Dhillon A, Rode J. PGP 9.5-a new marker for vertebrate neurons and neuroendocrine cells. Brain Res. 1983 Nov;278(1-2):224-8. https://doi.org/10.1016/0006-8993(83)90241-x

19. Wilkinson KD. Roles of ubiquitinylation in proteolysis and cellular regulation. Annu Rev Nutr. 1995;15:161-89. https://doi.org/10.1146/ annurev.nu.15.070195.001113

20. Gong B, Leznik E. The role of ubiquitin C-terminal hydrolase L1 in neurodegenerative disorders. Drug News Perspect. $2007 \mathrm{JuL}$ Aug;20(6):365-70. https://doi.org/10.1358/dnp.2007.20.6.1138160

21. Setsuie R, Wada K. The functions of $\mathrm{UCH}-\mathrm{L} 1$ and its relation to neurodegenerative diseases. Neurochem Int. $2007 \mathrm{Jul}$ Sep;51(2-4):105-11. https://doi.org/10.1016/j.neuint.2007.05.007

22. Mondello S, Constantinescu R, Zetterberg $\mathrm{H}$, Andreasson U, Holmberg B, Jeromin A. CSF $\alpha$-synuclein and UCH-L1 levels in Parkinson's disease and atypical parkinsonian disorders. Parkinsonism Relat Disord. 2014 Apr;20(4):382-7. https://doi. org/10.1016/j.parkreldis.2014.01.011

23. Li Y, Wang Z, Zhang B, Zhe X, Wang M, Bai J, et al. Cerebrospinal fluid ubiquitin C-terminal hydrolase as a novel marker of neuronal damage after epileptic seizure. Epilepsy Res. 2013 Feb;103(2-3):20510. https://doi.org/10.1016/j.eplepsyres.2012.08.001

24. Bradley WG, Daroff RB, Fenichel GM, Jankovic J. Neurology in clinical practice (principles of diagnosis and management). $4^{\text {th }} \mathrm{ed}$. Philadelphia: Butterworth Heinemann, 2004.

25. Lancman ME, Brotherton TA, Asconapé JJ, Penry JK. Psychogenic seizures in adults: a longitudinal study. Seizure 1993;2(4):281-6. http://dx.doi.org/10.1016/S1059-1311(05)80141-4

26. Chen DK, So YT, Fisher RS. Use of serum prolactin in diagnosing epileptic seizures: report of the Therapeutics and Technology Assessment Subcomittee of the American Academy of Neurology. Neurology 2005;65(5):668-75. ttp://dx.doi.org/10.1212/01. wnl.0000178391.96957.d0

27. Shah AK, Shein N, Fuerst D, Yangala R, Shah J, Watson C. Peripheral WBC count and serum prolactin level in various seizure types and nonepileptic events. Epilepsia 2001;42(11):1472-5. http://dx.doi. org/10.1046/j.1528-1157.2001.11901.x 